\title{
Protein-Energy Intakes and Nutritional Status of in-School Adolescents in Baham, Cameroon
}

Hernan Brice Kenmogne-Domguia ${ }^{1}$, Roger Ponka ${ }^{2}$ and Elie Fokou ${ }^{1^{*}}$

${ }^{1}$ Department of Biochemistry, Faculty of Science, University of Yaoundé I, PO BOX 812 Yaoundé, Cameroon

${ }^{2}$ Department of Agriculture, Livestock and Derivated Products, The Higher Institute of the Sahel, University of Maroua, PO BOX 46, Maroua, Cameroon

"Corresponding author: Elie Fokou, Department of Biochemistry, Faculty of Science, University of Yaoundé I, PO BOX 812 Yaoundé, Cameroon, Tel: 00237 677735816; E-mail: elfokou@yahoo.fr

Rec date: March 21, 2016; Acc date: April 07, 2016; Pub date: April 14, 2016

Copyright: @ 2016 Kenmogne-Domguia BH, et al. This is an open-access article distributed under the terms of the Creative Commons Attribution License, which permits unrestricted use, distribution, and reproduction in any medium, provided the original author and source are credited.

\begin{abstract}
Poor nutritional status during adolescence is an important determinant of health outcomes at a later stage of life. Therefore, attention should be given to adolescent health and nutrition. The aim of the present study was to investigate the protein-energy intakes and nutritional status of in-school adolescents in Baham, Central sub-division of the upper plateau division of the western Region of Cameroon. A total of 770 in-school adolescents of Baham aged between 10 and 18 years were recruited for the study. Protein and energy intakes were estimated based on their food consumption recorded using a 7-days food diary. Protein and energy intakes obtained were compared with reference values. Anthropometric measurements included weight and height were analysed using the World Health Organizations' (WHO) AnthroPlus ${ }^{\circledR}$ version 1.0.2 statistical software. No significant differences were observed in the daily intakes in protein and energy ( $p>0.05$ ) between male and female adolescents from 10 to 13 years. However, for adolescents aged 14 to 18 , the daily intakes in proteins and energy were significantly higher for males compared to females $(p<0.05)$. For all the subjects the protein intake was significantly higher than the needs while the energy intake was significantly lower than the needs $(p<0.05)$. The prevalence of stunted and wasted was significantly higher in males than the females $(p<0.05)$. In the contrary, the prevalence of overweight is significantly higher for females than for males $(p<0.05)$. These results will be useful for nutritional advice and intervention in adolescent males and females in this community.
\end{abstract}

Keywords: Protein intake; Energy intake; Nutritional status; School adolescents; Baham; Cameroon

\section{Introduction}

Malnutrition continues to be a major public health problem throughout the developing world, particularly in southern Asia and Sub-Saharan Africa [1,2]. The global prevalence of malnutrition is $13.6 \%$, with the greatest proportion of the affected population found in the developing world [3]. Diets, in these populations are frequently deficient in macronutrients (protein, carbohydrates and fat), micronutrients (electrolytes, minerals and vitamins) or both $[4,5]$. Malnutrition is consequently the most important risk factor for the burden of disease in developing countries [6]. It is the direct cause of about 300,000 deaths per year and is indirectly responsible for about half of all deaths in young children [7]. The risk of death is directly correlated with the degree of malnutrition [8].

In Cameroon, approximately 45,000 children die each year due to malnutrition [9]. The prevalence of chronic malnutrition is $31.7 \%$ for children younger than 5 years old [10]. The latest nutrition survey conducted by the National Statistics Institute reported high rate and increasing prevalences of stunting (33\%), underweight (15\%) and wasting $(6 \%)$ in children under 5 years [11]. The nutritional status of a population is an indicator of the level of development and future potential of the community. Determinants of child malnutrition should be periodically studied to monitor the situation and it is important to have appropriate interventions to prevent malnutrition [12].
Most studies of malnutrition in developing countries have focused on children under 5 year of age. There is relatively little nutritional informations available for adolescents, the age group with the highest growth velocity after infancy. According to the World Health Organization adolescence is a stage of development which corresponds roughly to the ages between 10 and 19 years [13]. In schooled adolescents, malnutrition and illness act as impediments to overall performance in school, as well as severely impairing psychomotor and intellectual development [14]. Adolescents have very special nutritional needs due to their rapid growth (lean body mass, fat mass, bone mineralization) and maturational changes associated with the onset of puberty.

According to nutritional surveys carried out mostly in developed world, many adolescents do not meet dietary requirements for their age group due to inadequate dietary intake of energy and proteins. Some adolescents have, however, problems with dietary excesses resulting in overweight and obesity as well as dietary inadequacies resulting in underweight [15]. Poor nutritional status during adolescence is an important determinant of health outcomes at a later stage of life. Therefore, attention should be given to adolescent health and nutrition. The aim of the present study was to investigate the protein-energy intakes and nutritional status of in-school adolescents in Baham, West Region of Cameroon. 


\section{Materials and Methods}

\section{Study area}

The study was carried out in Baham, situated in the West Region of Cameroon. It is the Central sub-division of the upper plateau division of the western Region. It lies between latitudes $5^{\circ} 15^{\prime} \mathrm{N}$ and $5^{\circ} 21^{\prime} \mathrm{N}$ to the North of the equator, and between longitudes $10^{\circ} 21^{\prime} \mathrm{E}$ and $10^{\circ} 27^{\prime} \mathrm{E}$. It has a subtropical climate. Its population is estimated at about 51,567inhabitants [16]. In Baham, farming is the main occupation. The dishes consumed in Baham are prepared mostly from sweet potatoes, yams, cassava, unripe bananas, maize, soybeans, beans, peanuts, egusi seeds and green leafy vegetables [17].

\section{Sample population and sampling procedure}

Schooled adolescents of Baham aged between 10 and 18 years were recruited. A total of 770 subjects ( 345 adolescents aged 10-13 years and 425 adolescents aged 14-18 years) participated in the study. The Schooled adolescents were divided into two groups (10-13 years and 14-18 years) according to their nutrient needs established by the Food and Nutrition Board of the Institute of Medicine (IOM) [18]. To be selected for the study, the Schooled adolescents had to be a permanent resident of Baham. Individuals were selected according to the ethnic homogeneity, allowing to limit the influence of the genetic factor on the variability of measurements, phenomenon which generally occurs at school age children and teenagers [19]. Moreover this homogeneity limits interethnic variability in food consumption. Screening questionnaires were completed to ensure that children were healthy. Adolescents were excluded from the study if they had been hospitalized within the past 3 months or were suffering from a medical condition that affected dietary intake.

\section{Dietary assessment}

Protein and energy intakes were estimated from a 7-day measured inventory of food and drink. This method has been successfully used and validated with young people aged $4-18$ years [20]. During a survey of the cooking methods and the consumption of the dishes in families chosen randomly in Baham, a scale (precision \pm 1 g; Philips HR-2393, Hungary) was used to determine the exact quantity of each dish contained in one standard household measures (such as cups, tablespoons, etc.). All adolescents were issued a food record diary and standard household measures. Verbal instructions were given on how to complete the diaries. Protein and energy intakes were calculated from the dietary record of schoolchildren using data of literature and the Baham food composition table established by Fokou et al. [17]. Protein and energy intakes obtained were compared with reference values.

\section{Anthropometric indices}

Anthropometric measurements included body weight and height, measured according to standard procedures described by Cogill [21]. Body weight, in light clothing with no shoes, was determined to the nearest $0.1 \mathrm{~kg}$ on a calibrated portable physician's scale. Height was measured to the nearest $0.5 \mathrm{~cm}$ with a Scales 2000 portable stadiometer. All measurements were taken twice. The average of the two measurements was recorded. Anthropometric data for the adolescents were analyzed using the WorldHealth Organizations' (WHO) AnthroPlus ${ }^{\oplus}$ version 1.0.2 statistical software. Stunting was defined as a height-for-age $\mathrm{z}$ score $<-2$ standard deviations (SD), wasting as a BMI-for-age $\mathrm{z}$ score $<-2 \mathrm{SD}$ and overweight as a BMI-forage $\mathrm{z}$ score $>+1$ SD [22]. Approval was obtained from the schools authorities prior to the commencement of the research. The teachers, students, and parents were well-informed of the scope and extent of the survey. Parents and adolescents signed a written informed consent.

\section{Statistical analysis}

After adequately verifying the data distribution by the KolmogorovSmirnov test, the values for protein and energy intakes were compared with the reference values, using the Student t-test. The other results were analyzed using the Mann-Whitney $U$ test. All statistical analyses were done with SPSS package (version 10.07) and the significant level was set at $\mathrm{p}<0.05$.

\section{Results}

\section{Population Distribution}

Table 1 shows the distribution of subjects in relation to their age group. Adolescents from 10 to 13 years represented $44.8 \%$ of the population with $20.4 \%$ of males and $24.4 \%$ of females. Adolescents from 14 to 18 years represented more than one-half of the population (55.2\%) with $26.1 \%$ of males and $29.1 \%$ of females.

\begin{tabular}{|l|l|l|l|}
\hline Age group & Males & Females & Total \\
\hline $10-13$ years & $157(20.4)$ & $188(24.4)$ & $345(44.8)$ \\
\hline $14-18$ years & $201(26.1)$ & $224(29.1)$ & $425(55.2)$ \\
\hline \multicolumn{2}{|l}{ Data presented as $\mathrm{n}(\%)$} & \\
\hline
\end{tabular}

Table 1: Distribution of subjects in relation to the age group $(n=770)$.

\section{Protein and energy intakes and coverage rate of subjects' needs}

Table 2 presents the average daily protein and energy intakes of subjects. No significant differences were observed in the daily intakes in protein and energy $(\mathrm{p}>0.05)$ between male and female adolescents from 10 to 13 years. On the other hand, the daily intakes in proteins and energy were significantly higher in male than the female adolescents from 14 to 18 years $(\mathrm{p}<0.05)$.

\begin{tabular}{|c|c|c|c|}
\hline Parameters & Males & Females & Total \\
\hline $10-13$ years & $\mathrm{n}=157$ & $\mathrm{n}=188$ & $\mathrm{n}=345$ \\
\hline Protein (g/day) & $42.13 \pm 12.36$ & $42.34 \pm 11.70$ & $42.24 \pm 12.03$ \\
\hline $\begin{array}{c}\text { Energy (Kcal/ } \\
\text { day) }\end{array}$ & $1835.58 \pm 496.32$ & $1820.93 \pm 440.17$ & $\begin{array}{c}1828.26 \pm \\
468.25\end{array}$ \\
\hline $\begin{array}{c}14-18 \text { years } \\
\text { Protein (g/day) }\end{array}$ & $\mathrm{n}=201$ & $\mathrm{n}=224$ & $\mathrm{n}=425$ \\
\hline $\begin{array}{c}\text { Energy (Kcal/ } \\
\text { day) }\end{array}$ & $2401.19 \pm 748.14^{*}$ & $2072.92 \pm 511.47$ & $\begin{array}{c}2237.06 \pm \\
629.80\end{array}$ \\
\hline \multirow{2}{*}{ * significant difference at the threshold $\mathrm{p}<0.05$ between sex. Comparison by } \\
\multicolumn{4}{|r}{ Mann-whitney U test } \\
\hline
\end{tabular}

Table 2: Average daily protein and energy intakes of subjects. 
Table 3 compares intake and need (reference value) in protein and energy and determination of the coverage rate in subjects. In both groups, the intake in proteins was significantly higher than the needs for males and females, while their energy intake was significantly lower than the needs $(\mathrm{p}<0.05)$.

\begin{tabular}{|c|c|c|c|c|c|c|}
\hline & \multicolumn{3}{|l|}{ Males } & \multicolumn{3}{|l|}{ Females } \\
\hline & Intake & Need $^{* *}$ & $\begin{array}{l}\text { Coverage } \\
\text { rate }(\%)\end{array}$ & Intake & Need $^{\star *}$ & $\begin{array}{l}\text { Coverage } \\
\text { rate }(\%)\end{array}$ \\
\hline \multicolumn{7}{|l|}{$10-13$ years } \\
\hline $\begin{array}{l}\text { Protein (g/ } \\
\text { day) }\end{array}$ & $42.13^{*}$ & 34 & 123.91 & $42.34^{*}$ & 34 & 124.53 \\
\hline $\begin{array}{l}\text { Energy } \\
\text { (Kcal/day) }\end{array}$ & $1835.58^{*}$ & 2279 & 80.54 & $1820.93^{*}$ & 2071 & 87.93 \\
\hline \multicolumn{7}{|l|}{$14-18$ years } \\
\hline $\begin{array}{l}\text { Protein (g/ } \\
\text { day) }\end{array}$ & $54.48^{*}$ & 52 & 104.77 & $48.82^{*}$ & 46 & 106.13 \\
\hline $\begin{array}{l}\text { Energy } \\
\text { (Kcal/day) }\end{array}$ & $2401.19^{*}$ & 3152 & 76.18 & 2072.92 & 2368 & 87.54 \\
\hline
\end{tabular}

" = significant difference at the threshold $p<0.05$ between intake and need Comparison by student's t-test for sigle sample. ${ }^{* *}=$ need established by the Institute of Medicine [18]

Table 3: Comparison between protein and energy intakes and need (reference values) and determination of coverage rate in subjects.

\section{Distribution of the subjects according to the nutritional} status

\begin{tabular}{|l|l|l|l|}
\hline Parameters & Males & Females & Total \\
\hline $10-13$ years & $\mathrm{n}=157$ & $\mathrm{n}=188$ & $\mathrm{n}=345$ \\
\hline Normal (\%) & $76.50^{*}$ & 75 & 75.75 \\
\hline Stunted (\%) & $11.50^{*}$ & 8.4 & 9.95 \\
\hline Wasted (\%) & $0.4^{*}$ & 0 & 0.2 \\
\hline Overweight (\%) & $11.6^{*}$ & 16.6 & 14.1 \\
\hline $14-18$ years & 201 & 224 & 425 \\
\hline Normal (\%) & $62.8^{*}$ & 67.1 & 64.95 \\
\hline Stunted (\%) & $28.3^{*}$ & 6.2 & 17.25 \\
\hline Wasted (\%) & $0.5^{*}$ & 0 & 0.25 \\
\hline Overweight (\%) & $8.4^{*}$ & 26.7 & 17.55 \\
\hline
\end{tabular}

${ }^{*}=$ significant difference at the threshold $p<0.05$ between sex. Comparison by Mann-whitney U test

Table 4: Distribution of subjects according to the nutritional status.

Table 4 presents the distribution of the subjects according to the nutritional status. In adolescents aged 10-13 years, the prevalence of stunted and wasted were significantly higher $(\mathrm{p}<0.05)$ for males $(11.50 \%$ and $0.4 \%$, respectively) than for females $(8.4 \%$ and $0.0 \%$ respectively). In the contrary, the prevalence of overweight was significantly higher $(\mathrm{p}<0.05)$ for females $(16.6 \%)$ than for males
(11.6\%). In adolescents aged 14-18 years, the prevalence of stunted and wasted were also significantly higher $(\mathrm{p}<0.05)$ for males $(28.3 \%$ and $0.5 \%$ respectively) than for females $(6.2 \%$ and $0.0 \%$, respectively). In this age group, the prevalence of overweight was also significantly higher $(\mathrm{p}<0.05)$ for females $(26.7 \%)$ than for males $(8.4 \%)$.

\section{Discussion}

\section{Protein and energy intakes and coverage rate of subjects' needs}

The daily intakes in proteins and energy (Table 2) were higher for male $(54.48 \mathrm{~g} /$ day; $2401.19 \mathrm{Kcal} /$ day, respectively) than for female ( $48.82 \mathrm{~g} /$ day; $2072.92 \mathrm{Kcal} /$ day, respectively) adolescents from 14 to 18 years. The difference observed was due to the difference in the quantity of food consumed by each sex. The protein intake of adolescents aged 10-13 years (Table 2) was low compared with the $45.2 \mathrm{~g} /$ day obtained by Priyanka Gupta et al. [23] among adolescent girls residing in an Urban Slum of Delhi (India). On the other hand the protein intake of adolescents 14-18 years (Table 2) was high compared with the 28.30, 45.2 and $50.4 \mathrm{~g} /$ day obtained by Ponka et al. [24] in aldolescents cameroonian school children of Ngali II, Priyanka Gupta et al. [23] among adolescent girls residing in an Urban Slum of Delhi and Charukatare and Madhubala [25] among adolescent Girls Pursuing Undergraduate Studies at Orai (India), respectively. But the protein intake of adolescents 14-18 years (Table 2) was low compared with 62.7 g/day obtained by Doustmohammadian et al. [26] among adolescent girls in Tehran (Iran) and $59 \mathrm{~g}$ /day obtained by Gibson [27] in adolescents in Great Britain.

The energy intake of adolescents $10-13$ years (1828.26 kcal/day) (Table 2) was high compared with the $1654 \mathrm{kcal} /$ day obtained by Priyanka Gupta et al. [23] among adolescent girls residing in An Urban Slum of Delhi. The energy intake of adolescents 10-13 years was also high compared with the $1793 \mathrm{kcal} /$ day obtained by Tornaritis et al. [28] in Cypriot adolescents. The energy intake of adolescents 14-18 years (2237.06 kcal/day) (Table 2) was high compared with $1649 \mathrm{kcal} /$ day obtained by Charukatare and Madhubala et al. [25] among adolescent girls residing in an Urban Slum of Delhi. It was also high compared with the $1957.4 \mathrm{kcal} /$ day obtained by Doustmohammadian et al. [26] among adolescent girls in Tehran (Iran).

The protein intake (Table 3 ) in all subjects was sufficient to cover the nutritional need established by the IOM [18]. In the contrary, the energy intake (Table 3 ) in all subjects was insufficient to cover the nutritional need. Protein plays a lot of important functions in the human body and in fact the human body is about $45 \%$ protein. They are essential macromolecules without which our bodies would be unable to repair, regulate, or protect itself. Essential body processes such as water balancing; nutrient transport and muscle contractions require protein to function [29]. Protein deficiency causes growth retardation, muscle wasting, edema, abnormal swelling of the belly and collection of fluids in the body [30] (Mounts, 2000). Previous studies like those of Tanner et al. (1987) in Tanzania, Pereira et al. [31,32] (1995) and Razanamparany et al. [33] in Madagascar, Man et al. [34] in Gambia, and Tonglet et al. [35] in Central Africa showed that proteincalorie malnutrition favors the evolution of malaria. 


\section{Distribution of the subjects according to the nutritional status}

The low prevalence of stunted (9.95-17.25\%) and wasted $(0.2-0.25 \%)$ in the population (Table 4$)$ may be due to the appropriate protein intake. The high prevalence of stunted (11.50-28.3\%) and wasted (0.4-0.5\%) in males compared to females (6.2-8.4\%) stunted and $(0 \%)$ wasted would be related to relative low energy intake which could divert amino acid for energy production. The high prevalence of stunting and wasting in males may also be explained by the physical activity which is usually important in males compare to females. The high prevalence of overweight in females would be due to the fact that the coverage of energy was better in females $(87 \%)$ and may be boys of this age were more active than girls. Moreover during the period of adolescence, females attend the puberty with the increase on their weight.

\section{Conclusion}

From this study, no significant difference was observed in the daily intakes in protein and energy between male and female adolescents from 10 to 13 years. On the other hand, the daily intakes in protein and energy was significantly higher in male than the female adolescents from 14 to 18 years. In all subjects, the intake in protein was significantly higher than the needs while their energy intake was significantly lower than the needs. In adolescents, the prevalence of stunted and wasted was significantly higher in male than the female. In the contrary, the prevalence of overweight was significantly higher in females than the males. These results will be useful for nutritional advice and intervention in adolescent males and females in this community.

\section{Acknowledgments}

We thank the Schooled adolescents of Baham who have accepted to participate in this work.

\section{References}

1. Food and Agriculture Organization of the United Nations (2004) Undernourishment around the world. In: The state of food insecurity in the world 2004 Rome.

2. World Health Organization (2004) United Nations Childrens Fund. Joint statement on the management of acute diarrhea, Geneva.

3. FAO (2011) World Hunger and Poverty Facts and Statistics.

4. Brabin BJ, Coulter JBS (2003) Nutrition-associated disease. In: Cook GC, Zumla AI, editors. Mansons tropical diseases. London.

5. Millward DJ, Jackson AA (2004) Protein/energy ratios of current diets in developed and developing countries compared with a safe protein/energy ratio: implications for recommended protein and amino acid intakes. Public Health Nutr 7: 387-405.

6. Black R (2003) Micronutrient deficiency--an underlying cause of morbidity and mortality. Bull World Health Organ 81: 79.

7. Black RE, Morris SS, Bryce J (2003) Where and why are 10 million children dying every year? Lancet 361: 2226-2234.

8. Fernandez ID, Himes JH, De Onis M (2002) Prevalence of nutritional wasting in populations: building explanatory models using secondary data. Bull World Health Organ 80: 282-291.

9. UNICEF Cameron (2009) Humanitarian action update. Silent emergency affecting children in cameroon. Yaounde Cameroon.

10. Enquetes Demographiques de la Sante au Cameroun (2004) Rapport des resultats de la 3eme enquete de demographie et de sante au Cameroun. Institut National de la Statistique, Yaounde, Cameroun.
11. EDS-MICS (2001) Rapport preliminaire. Institut national de la statistique. Republique du Cameroun.

12. Adel ET, Francoise M, Salaheddin M, Najeeb E, Ahmed AM, et al. (2008) Nutritional status of under-five children in Libya, a national populationbased survey. Libyan J Med 3: 13-19.

13. World Health Organization (2003) Nutrition in adolescence. Issues and Challenges for the Health Sector. Issues in Adolescent Health and Development, Geneva, Switzerland.

14. Ivanovic D, Leiva BP, Perez HT, Almagia AF, Toro TD, et al. (2002) Nutritional status, brain development and scholastic achievement of Chilean high school graduates from high and low intellectual quotient and socio-economic status. Br J Nutr 87: 81-92.

15. Barbara AB, Robert MR (2001) Present knowledge in nutrition (8thedn). Washington.

16. RGPH (2010) Recensement General des Populations et de 1 Habitat, 3eme Rapport d OMD par le bureau central de recensement de la population (BUCREP).

17. Fokou E, Ponka R, Tchinda Dimofo PH, Domguia Kenmogne H B, Tchouba LB, et al. (2009) Methods of preparation and nutritive value of some dishes consumed in the West region of Cameroon. Pak J Nutr 8: 1190-1195.

18. Institute of Medicine (IOM) (2002) Dietary reference intakes for energy, carbohydrate, fiber, fat, fatty acids, cholesterol, protein and amino acids (macronutrients). National Academy Press, Washington.

19. Woodruff BA, Duffield A (2002) Anthropometric assessment of nutritional status in adolescent populations in humanitarian emergencies. Eur J Clin Nutr 56: 1108-1118.

20. Gregory J, Lowe S, Bates CJ, Prentice A, Jackson LV (2000). National Diet and Nutrition Survey: Young People Aged 4-18 Years. London.

21. Cogill B (2003) Anthropometric Indicators Measurement Guide, Technical Project Assistance The power supply to and Nutrition, Academy for the Development of Education, Washington.

22. WHO (2010) The WHO child growth standards. World Health Organization.

23. Priyanka Gupta B, Totaja GS, Neena (2015) Nutrient Intake amongst Adolescent Girls Residing In An Urban Slum Of Delhi. Indian J Appl Res 2: 288-290.

24. Ponka R, Fokou E (2011) Dietary intake, zincemia and cupremia of Cameroonian schoolchildren of Ngali II. See comment in PubMed Commons below Int J Food Sci Nutr 62: 377-384.

25. Charukatare MC (2015) Assessment of Dietary Intake, Routine Physical Activities and BMI of Adolescent Girls Pursuing Undergraduate Studies at Orai, UP. IJHSR 5: 284-290.

26. Doustmohammadian A, Keshavarz AS, Doustmohammadian S, Abtahi M, Shahani M (2013). Nutritional status and dietary intake among adolescent girls. JPS 4: 72-77.

27. Gibson S1 (2010) Trends in energy and sugar intakes and body mass index between 1983 and 1997 among children in Great Britain. See comment in PubMed Commons below J Hum Nutr Diet 23: 371-381.

28. Tornaritis MJ, Philippou E, Hadjigeorgiou C, Kourides AY, Panayi A (2014) Study of the dietary intake of Cypriot children and adolescents aged 6-18 years and the association of mothers educational status and childrens weight status on adherence to nutritional recommendations. BMC Public Health 14:1-11.

29. Robert K M, Dary IK (2006) Victor W. Harpers Biochemistry (27thedn).

30. Mounts TL (2000) The Chemistry of Components. (2ndedn) Royal Society of Chemistry.

31. Tanner M, Buurnier E, Mayombana C (1987) Longitudinal study on the health status in a rural Tanzanian community: Parasitosis and nutrition following control measures against intestinal parasites. Acta Trop 44: 137-174.

32. Pereira PC, Meira DA, Curi PR, de Souza N, Burini RC (1995) The malarial impact on the nutritional status of Amazonian adult subjects. Rev Inst Med Trop Sao Paulo 37: 19-24. 
Citation: Kenmogne-Domguia BH , Ponka R, Fokou E (2016) Protein-Energy Intakes and Nutritional Status of in-School Adolescents in Baham, Cameroon. J Nutr Disorders Ther 6: 186. doi:10.4172/2161-0509.1000186

Page 5 of 5

33. Razanamparany MS, Randriamiharisoa FA, Razanamparany NJ, Ramialimanana V (1995) [The malaria epidemic in Antananarivo from 1983 to 1994 as seen through the Pediatric Service A in the Befelatanana General Hospital]. Sante 5: 382-385.

34. Man WD, Weber M, Palmer A, Schneider G, Wadda R, et al. (1998) Nutritional status of children admitted to hospital with different diseases and its relationship to outcome in The Gambia, West Africa. Trop Med Int Health 3: 678-686.

35. Tonglet R, Mahangaiko Lembo E, Zihindula PM, Wodon A, Dramaix M, et al. (1999) How useful are anthropometric, clinical and dietary measurements of nutritional status as predictors of morbidity of young children in central Africa? Trop Med Int Health 4: 120-130. 